\title{
Release of SF3 from the intron branchpoint activates the first step of pre-mRNA splicing
}

\author{
REA M. LARDELLI, ${ }^{1}$ JAMES X. THOMPSON, ${ }^{2}$ JOHN R. YATES III, ${ }^{2}$ and SCOTT W. STEVENS ${ }^{3,4}$ \\ ${ }^{1}$ Graduate Program, Department of Chemistry and Biochemistry, University of Texas at Austin, Austin, Texas 78712, USA \\ ${ }^{2}$ Scripps Research Institute, La Jolla, California 92037, USA \\ ${ }^{3}$ Section in Molecular Genetics and Microbiology, University of Texas at Austin, Austin, Texas 78712, USA \\ ${ }^{4}$ Institute for Cellular and Molecular Biology, University of Texas at Austin, Austin, Texas 78712, USA
}

\begin{abstract}
Eukaryotic pre-mRNA splicing is a complex process requiring the precise timing and action of $>100$ trans-acting factors. It has been known for some time that the two steps of splicing chemistry require three DEAH-box RNA helicase-like proteins; however, their mechanism of action at these steps has remained elusive. Spliceosomes arrested in vivo at the three helicase checkpoints were purified, and first step-arrested spliceosomes were functionally characterized. We show that the first step of splicing requires a novel ATP-independent conformational change. Prp2p then catalyzes an ATP-dependent rearrangement displacing the SF3a and SF3b complexes from the branchpoint within the spliceosome. We propose a model in which SF3 prevents premature nucleophilic attack of the chemically reactive hydroxyl of the branchpoint adenosine prior to the first transesterification. When the spliceosome attains the proper conformation and upon the function of Prp2p, SF3 is displaced from the branchpoint allowing first step chemistry to occur.
\end{abstract}

Keywords: ribonucleoprotein; spliceosome; RNA helicase; splicing mechanisms

\section{INTRODUCTION}

Eukaryotic protein-coding RNAs often contain one or more noncoding, intervening sequences (introns), which are removed in a two-step process within a massive ribonucleoprotein (RNP) termed the spliceosome (Brody and Abelson 1985). Inaccurate splicing leads to the production of mRNAs that do not authentically represent the intended gene product, thus, introns must be precisely removed to ensure the proper outcome. Indeed, pre-mRNA splicing defects have been correlated to a substantial percentage of human diseases including cancer (for review, see Faustino and Cooper 2003). Defining the mechanisms underlying the assembly of the spliceosome, the authorization for initiating the two chemical steps and proofreading of the splice sites are critical to a full understanding of pre-mRNA splicing.

Spliceosomal introns vary in size by a factor of almost 500 (from tens to thousands of nucleotides) and possess only three common, degenerate motifs at the $5^{\prime}$ splice site, $3^{\prime}$ splice site, and the branchpoint. In addition, the mech-

Reprint requests to: Scott W. Stevens, Section in Molecular Genetics and Microbiology, University of Texas at Austin, Austin, TX 78712, USA; e-mail: scott.stevens@mail.utexas.edu; fax: (512) 471-7088.

Article published online ahead of print. Article and publication date are at http://www.rnajournal.org/cgi/doi/10.1261/rna.2030510. anism of pre-mRNA splicing is chemically indistinguishable from that of group II intron splicing, which can occur in the absence of trans-acting proteins and RNAs (for review, see Bonen and Vogel 2001). Although both intron types possess a $5^{\prime}$ splice site, a $3^{\prime}$ splice site, and a branchpoint sequence, spliceosomal introns lack the sequences and structures that group II introns possess for their removal. Thus accurate intron removal requires the regulated efforts of >100 snRNP- and non-snRNP-associated factors for the proper assembly of the substrate in the spliceosome and the precise formation of and rearrangements within the catalytic core of the spliceosome. Among these factors are eight highly conserved RNA helicase-like proteins of the DExH/D family (for review, see Staley and Guthrie 1998). Prp2p is required for the first chemical step (Chen and Lin 1990; King and Beggs 1990), and Prp16p (Schwer and Guthrie 1991) and Prp22p (Company et al. 1991) are required at the second step of the reaction, although the role of Prp22p at this step is ATP-independent (Schwer and Gross 1998). Although these factors have been studied for some time, the specific molecular rearrangements they initiate at each of the chemical steps have remained enigmatic for the last 20 years.

The first chemical step of splicing occurs when the $2^{\prime}-\mathrm{OH}$ of the branchpoint adenosine performs a nucleophilic attack 
at the phosphodiester bond of the $5^{\prime}$ splice site, releasing the $5^{\prime}$ exon and forming a branched lariat intermediate RNA (Domdey et al. 1984; Padgett et al. 1984; Ruskin et al. 1984). Prior to first step chemistry, the branchpoint sequence of the pre-mRNA is associated with the U2 snRNA by basepairing and bound by a number of U2 snRNP-associated proteins contained within two sub-complexes termed SF3a (Brosi et al. 1993) and SF3b (Will et al. 2002). The second step reaction occurs when the $3^{\prime}-\mathrm{OH}$ of the $5^{\prime}$ exon attacks the phosphodiester bond at the $3^{\prime}$ splice site, joining the exons and liberating the intron lariat RNA. Both steps of splicing require significant structural rearrangements in the spliceosome to properly place the reactive sites at its catalytic center (Konarska et al. 2006). Defining these rearrangements and the mechanisms by which they occur has been challenging due in part to the complexity of spliceosome assembly and the dynamic nature of the spliceosome.

In this work, we have purified functional, synchronized spliceosomes genetically arrested at three critical checkpoints in the splicing reaction in vivo to enrich for onpathway, functional complexes. Employing a biochemical approach, we analyzed spliceosomes stalled (1) prior to the first step (Fig. 1A, left panel), (2) prior to the second step (Fig. 1A, middle panel), and (3) prior to mRNA release (Fig. 1A, right panel) from the spliceosome. Compositional differences within these arrested spliceosomes were analyzed. Surprisingly, the multisubunit SF3a and SF3b complexes, which reside at and around the intron branchpoint (Macmillan et al. 1994; Gozani et al. 1996, 1998), are present prior to the first step and completely absent prior to the second step. We hypothesized that this release may coincide with the function of $\operatorname{Prp} 2 \mathrm{p}$ and that once the spliceosome is properly organized, SF3 removal may initiate the activation of first step chemistry.

To test this, we functionally characterized the first-stepstalled spliceosome assembled in vivo and showed that prior to catalysis, a novel ATP-independent conformational rearrangement is followed by an ATP-dependent displacement of SF3 from the spliceosome. Removal of SF3 from the chemically reactive $2^{\prime}-\mathrm{OH}$ of the branchpoint adenosine at this time allows the proper nucleophilic attack at the 5 ' splice site. Thus, in addition to its role in branchpoint identification and binding, we propose that the SF3 complex functions to restrain the branchpoint hydroxyl from chemistry until the catalytic core of the spliceosome is properly assembled.

\section{RESULTS}

\section{Characterization of first step-blocked spliceosomes}

Prp2p acts almost immediately upstream of the first step of pre-mRNA splicing; therefore, we isolated spliceosomes from Saccharomyces cerevisiae arrested prior to Prp $2 \mathrm{p}$ function. Prp2p-associated material was affinity purified from

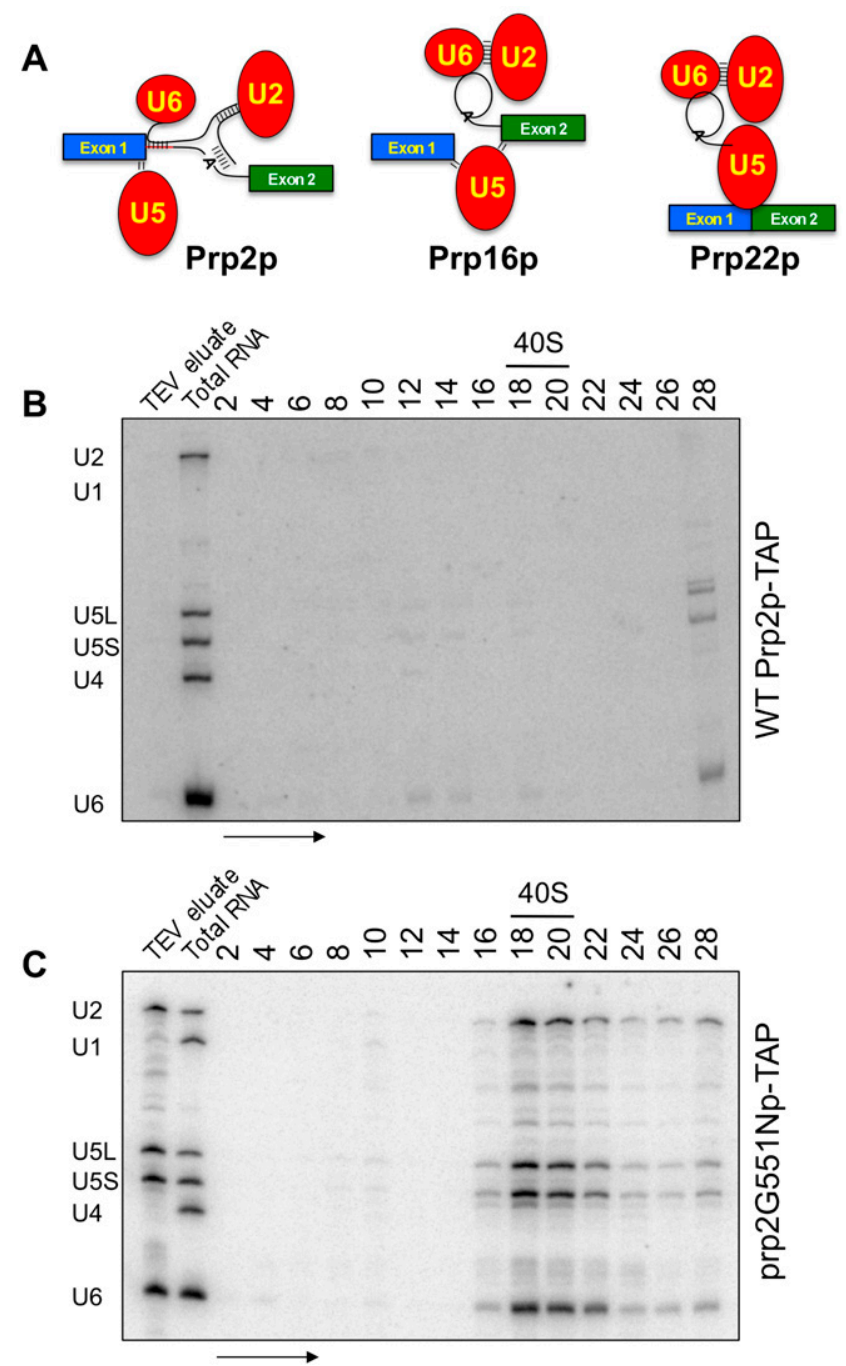

FIGURE 1. Purification of the first step arrested spliceosome. $(A)$ Graphical representation of the Prp2p- Prp16p- and Prp22p-arrested and -associated spliceosomes purified in this work. RNA from glycerol sedimentation gradients corresponding to affinity purified $(B)$ Prp2pTAP and $(C)$ prp2G551Np-TAP-associated material were Northern blotted for spliceosomal snRNAs. Splicing complexes are present only in the temperature-shifted mutant corresponding to the U2, U5, and U6 snRNAs sedimenting at $\sim 40$ S. Ribosomal subunits were used to determine the peak area of $40 \mathrm{~S}$ subunit sedimentation. The arrow indicates the direction of sedimentation. Positions of U1, U2, U4, U5, and U6 snRNAs are shown.

cells containing a TAP-tag (Puig et al. 2001) at the PRP2 locus in a wild-type strain. Prp2p-associated complexes were layered onto a glycerol velocity gradient suitable for spliceosome sedimentation (Stevens and Abelson 2002). Northern blot analysis of snRNAs in the even fractions from this gradient shows that Prp2p does not stably interact with significant levels of endogenous spliceosomes or spliceosomal snRNAs (Fig. 1B). Prp2p is a transiently interacting factor (King and Beggs 1990); thus, we did not expect this strategy to yield spliceosomes, but instead to serve as a control. 
To accumulate spliceosomes with which Prp2p is associated, but reversibly arrested prior to its ATPase-dependent function, we used a cold sensitive (cs) prp2 mutant that interacts with the spliceosome, but is unable to function at nonpermissive temperatures (NPTs). A yeast strain containing the severely cs G551N mutation of Prp2p (EdwaldsGilbert et al. 2000; also see Materials and Methods) was C-terminally TAP-tagged at the prp2 locus. Cells were shifted to the NPT of $25^{\circ} \mathrm{C}$ prior to harvesting, trapping endogenous pre-mRNAs in a first step-arrested spliceosome. ATP-depleted, affinity-purified prp2G551Np-associated material was layered onto a glycerol velocity gradient for spliceosome isolation. A significant peak of U2, U5, and U6 snRNAs at $\sim 40 \mathrm{~S}$ is seen in these gradients (Fig. 1C), corresponding to the size of the yeast spliceosome (Brody and Abelson 1985)

To compositionally define the first step-arrested spliceosome, we performed MudPIT mass spectrometry analysis of the associated polypeptides (Washburn et al. 2001). In Figure 2, we outline the protein components present in this and downstream spliceosomal RNPs. We note the complete absence of all but three tri-snRNP components in the prp2arrested spliceosome. Additionally, the first step-arrested spliceosome contains all of the known yeast SF3 components (Dziembowski et al. 2004). Also present in the first step blocked spliceosome were the Sm core proteins of the U2 and U5 snRNPs (Séraphin 1995) and the U2 core proteins Lea1p and Msl1p (U2A' and $\mathrm{U}^{\prime} \mathrm{B}^{\prime \prime}$, respectively in human) (Caspary and Séraphin 1998). We did not detect any U6-specific LSm proteins (Achsel et al. 1999; Stevens et al. 2001) consistent with their reported destabilization during spliceosome activation (Chan et al. 2003). The entire Prp19p complex (NTC) was identified and remains bound throughout the splicing cycle during the window of time analyzed in these experiments, just prior to the first step until the splicing reaction has completed (Fig. 2). The second step factor Prp17p was detected prior to the first step and remains bound throughout splicing, consistent with a recent report (Sapra et al. 2008). Two pre-mRNA binding proteins (Stolp and Cbc2p) comprising the capbinding complex (Colot et al. 1996; Lewis et al. 1996; Fortes et al. 1999) were consistently detected in all mass spectrometry results. A number of other spliceosome-associated proteins were detected as well (Fig. 2).

\section{Functional analysis of prp2-arrested spliceosomes}

Although Prp2p function initiates the first step of splicing, the recently described factor Yju2p was reported to be required after $\operatorname{Prp} 2 \mathrm{p}$, but prior to chemistry (Liu et al.

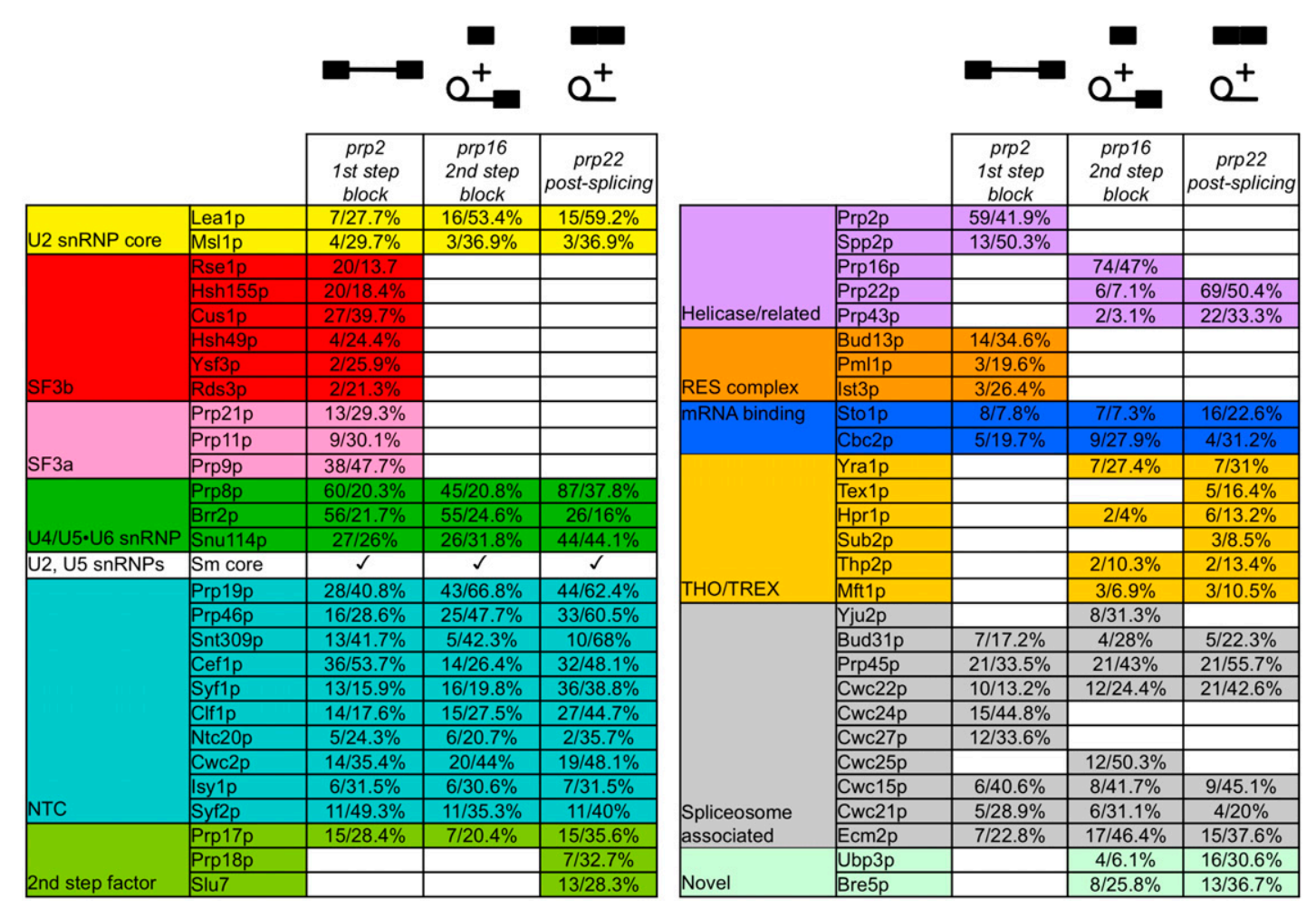

FIGURE 2. Mass spectrometry analysis of the associated proteins from first step-arrested, second step-arrested, and post-second step spliceosomes. Polypeptides corresponding to peak fractions from Figure 1C (prp2-arrested first step), Figure 5B (prp16-arrested second step), from Figure 5E (prp22-arrested spliceosomes) were analyzed by MudPIT. Proteins are categorized by group or functional association. Data for the number of peptides identified and percentage polypeptide sequenced are shown. Polypeptide contaminants are listed in Supplemental Table S1. 
2007). Yju2p is not detectable by mass spectrometry in this particle (Fig. 2), however to ensure that we could confidently distinguish between the functions of Prp2p and Yju2p in the arrested spliceosomes, we metabolically depleted Yju2p from prp2G551Np-TAP cells by repressing a GAL-driven, HA-tagged Yju2p (Fig. 3A; Longtine et al. 1998). We isolated first step-blocked spliceosomes by prp2G551Np-TAP chromatography from Yju2p-depleted cells that additionally contain a myc tag on Prp9p (Abovich et al. 1990; Legrain and Choulika 1990). Prp9p is the yeast homolog of mammalian SF3a60, which is a component of the U2 snRNP-associated trimeric SF3a complex. Purified, arrested spliceosomes were incubated under splicing conditions (Stevens and Abelson 2002) at NPT with no ATP treatment (Fig. 3B), under splicing conditions at permissive temperature (PT) with no ATP treatment (Fig. 3C), under splicing conditions at PT with AMP-PNP treatment (Fig. 3D), or under splicing conditions at PT with ATP (Fig. 3E). After incubation, the reactions were centrifuged through spliceosome-resolving glycerol velocity gradients. Proteins from alternating fractions were subjected to Western blot analysis to detect Prp9p-myc and nucleic acids subjected to Northern blot analysis to detect spliceosomal snRNAs. Spliceosomes incubated at NPT sedimented identically to those resulting from an untreated sample in which Yju2p was not depleted (cf. Fig. 1C and Fig. 3B). In samples treated at PT without ATP, the peak of the signal was shifted three fractions higher in the gradient (Fig. 3C), indicating a substantial change in shape or in composition. This indicates that the novel ATP-independent event may be catalyzed by $\operatorname{Prp} 2 \mathrm{p}$ itself and represents a conformational change rather than a compositional change and is corroborated by the AMP-PNP experiment in Figure 3D (see Discussion). Upon incubation at PT in the presence of ATP, Prp9p-myc is displaced from the spliceosome and sediments near the top of the gradient (Fig. 3E). A quantitative analysis of the sedimentation behavior of SF3 and the spliceosomes from Figure 3, B-E, is shown in
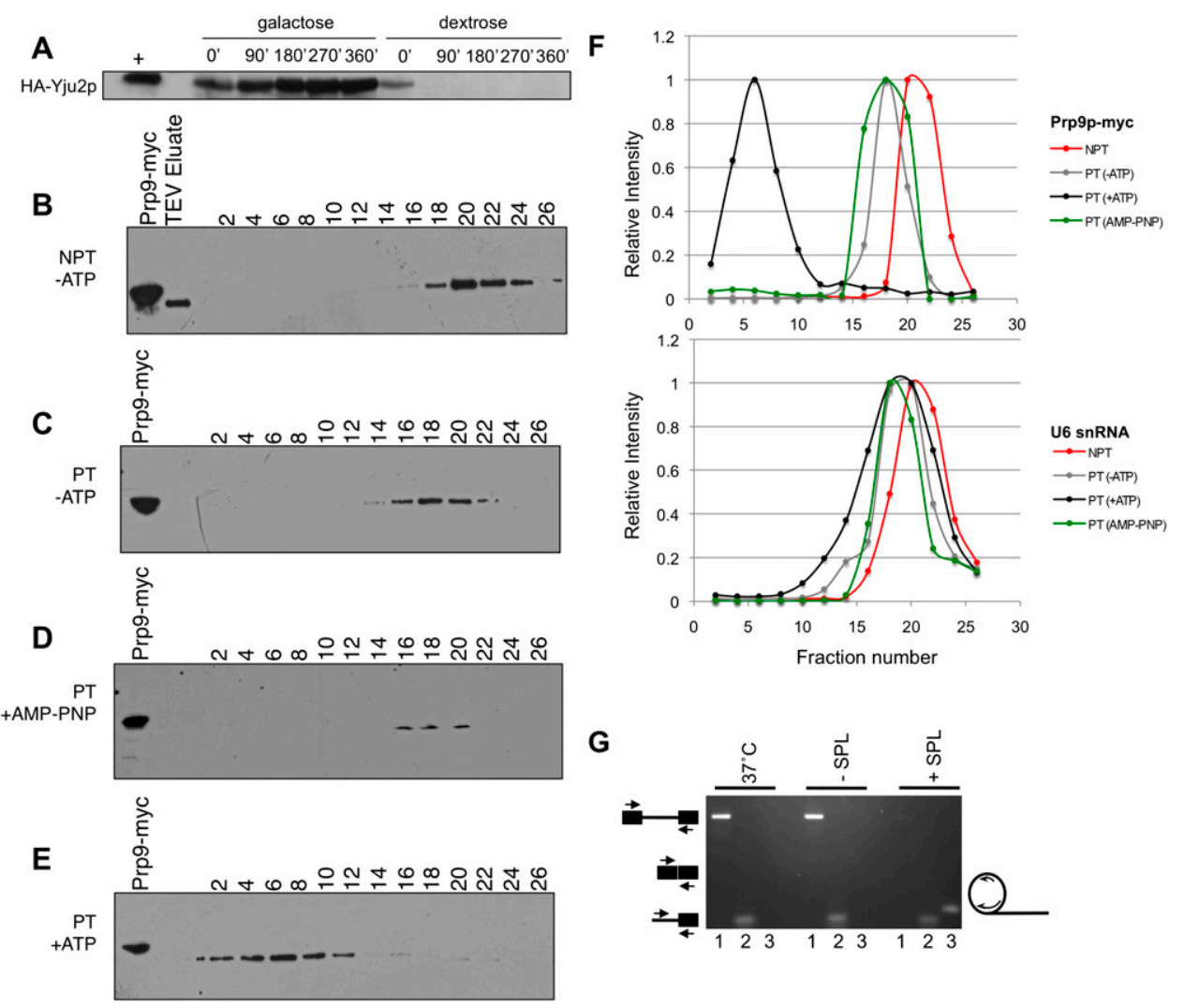

FIGURE 3. Functional characterization of the first step-arrested spliceosome. (A) Metabolic depletion of Yju2p from prp2G551N cells. Western blot analysis of GAL-HA-Yju2p through a time-course in galactose (left) or after shift to dextrose (right). Affinity-purified spliceosomes depleted for Yju2p and arrested at the first step of splicing using the prp2G551N mutation were treated at NPT with no added nucleotide $(B)$, treated at PT with no added nucleotide $(C)$, treated at PT with added ATP $(D)$, or treated at PT with AMP-PNP $(E)$. Proteins in the gradient fractions were subjected to Western blot analysis for Prp9-myc. $(F)$ Prp9p-myc signal was quantitated in gradient fractions from $B-E$, normalized and graphed (top panel). RNAs from the corresponding fractions were Northern blotted for snRNAs, which were quantitated, normalized, and graphed (bottom panel). (G) RT-PCR analysis of unspliced and partially spliced pre-mRNAs contained in the peak gradient fractions from $B$, $C$, and $E$. Lane 1 of each set is designed to amplify $R P P 1 B$ pre-mRNA and mRNA. Lane 2 of each set amplifies the RPP $1 B 3^{\prime}$ splice site junction. Lane 3 of each set specifically amplifies the ACT1 lariat structure using a splint oligonucleotide that bridges the intron sequences of the $5^{\prime}$ splice site and upstream of the branchpoint adenosine and another oligonucleotide that allows for specific amplification within the lariat structure. 
Figure 3F. The displacement of SF3 (Fig. 3F, top panel) does not affect the sedimentation of the spliceosome as defined by the U2, U5, and U6 snRNAs at the $\sim 40$ S region of this gradient (Fig. 3F, bottom panel).

To further demonstrate that the shifts in glycerol gradient sedimentation correspond to authentic changes in shape for these complexes, we also performed native gel electrophoresis on the purified complexes after TEV elution (Supplemental Fig. S1). The shape change noted by the shift in sedimentation upon incubation at PT with no ATP (Fig. 3, cf. B and C), the migration of comparable spliceosomes in a native gel are measurably different (Supplemental Fig. S1, cf. lanes 1 and 2). Further migration differences were noted in the presence of ATP at PT (Supplemental Fig. S1, lane 3) or in the presence of AMP-PNP (Supplemental Fig. S1, lane 4).

To demonstrate the functionality of these arrested spliceosomes, we performed RT-PCR analysis on RNAs contained in representative fractions from affinity-purified, gradient-separated material. Using a strategy to detect premRNA, lariat intermediate, and lariat, we show that premRNA was exclusively found in arrested spliceosomes from peak fractions of both of the reactions lacking ATP, as expected (Fig. 3G). This also indicates that the ATPindependent conformational change is not coincident with or sufficient to promote the first step. In the presence of ATP at PT and in the absence of Yju2p, the vast majority of pre-mRNA was chased to lariat intermediate (Fig. 3G). These data demonstrate that even if Yju2p is required for the first step of splicing a subset of introns, it is not required for the displacement of SF3 under these conditions, as most of SF3 is not spliceosome associated after Prp2p function.

\section{SF3b displacement is independent of Yju2p}

The SF3a heterotrimer is a subfraction of the SF3 activity characterized by Krämer and colleagues (Brosi et al. 1993). The other portion of SF3 activity, the U2 snRNPassociated SF3b, contains seven polypeptides in humans (Will et al. 2002) and six orthologous polypeptides in yeast (Dziembowski et al. 2004). SF3a and SF3b are both present in the assembled, prp2-arrested spliceosome (Fig. 2); however since each subcomplex can be isolated independently, they may behave very differently in terms of their release from the spliceosome.

To test for the displacement of both SF3a and SF3b, we employed a glycerol-cushion pelleting assay to test for their release. In this assay, we used conditions designed to pellet intact spliceosomes, but incapable of pelleting displaced SF3a or SF3b. First step-arrested spliceosomes containing either Prp9p-myc (an SF3a component) or Hsh155p-myc (an SF3b component) were affinity-purified. To enrich for a homogeneous population, spliceosomes were further purified by glycerol velocity gradient and the peak fraction was selected. Spliceosomes were then incubated under one of three conditions: (1) splicing conditions with no ATP at NPT (Fig. 4A, lanes 3,4); (2) splicing conditions with ATP at PT (Fig. 4A, lanes 5,6), or (3) treated in $1 \mathrm{M} \mathrm{NaCl}$ (Fig. $4 \mathrm{~A}$, lanes 7,8). The reactions were sedimented through a glycerol cushion to separate the spliceosome from released factors. Proteins extracted from the supernatant and the pellet were analyzed for the presence of the myc tag by Western blotting. The SF3a and SF3b complexes are known to be sensitive to elevated salt levels (Behrens et al. 1993; Bessonov et al. 2008); thus, the salt-treated samples serve as a control for displacement of SF3 from the purified spliceosome. Both SF3a and SF3b are displaced from the spliceosome upon Prp2p function only under splicing conditions (Fig. 4A lanes 5,6) as shown by the presence of Prp9p-myc and Hsh155p-myc in the supernatant. At NPT, they are found exclusively in the pellet.

We also affinity purified a first step-blocked, $\Delta Y j u 2 p$ spliceosome containing Hsh155p-myc to ensure that Yju2p was not required for SF3b displacement. The above strategy was used for analysis of the $\Delta \mathrm{Yju} 2 \mathrm{p}$ spliceosome containing Hsh155p-myc (Fig. 4B). Yju2p, which has been proposed to act downstream from Prp2p in the splicing cycle, is not required for the displacement of SF3b as SF3b is released upon the action of Prp2p in the absence of Yju2p (Fig. 4B, lanes 5,6) (see Discussion).

\section{Second step-arrested spliceosome characterization}

After the first step of splicing, two additional DEAH-box proteins are required to proceed through the second step. The second transesterification reaction requires an ATPasecatalyzed reaction carried out by Prp16p (Schwer and Guthrie 1991), followed by an ATP-independent event requiring Prp22p (in conjunction with several other second step factors (Schwer and Gross 1998)). Spliceosomes arrested at the second step of splicing were affinity purified from cs prp16 mutants. Prp16p was TAP-tagged in three strains:

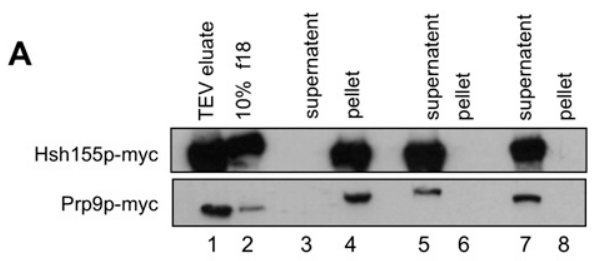

B

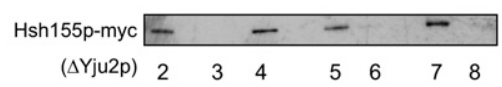

FIGURE 4. $\mathrm{SF} 3 \mathrm{a}$ and $\mathrm{SF} 3 \mathrm{~b}$ are released from the spliceosome concurrent with Prp2p action. (A) Affinity-purified spliceosomes were pelleted through glycerol cushions without splicing (lanes 3,4), with splicing (lanes 5,6), or after disruption with salt (lanes 7,8). Total proteins from supernatant and pellet fractions were Western blotted for the myc tag. (B) Same experiment performed for Hsh155p-myc in $A$ using affinity-purified $\Delta$ Yju2p spliceosomes. Lane 1 contains $2 \%$ of the TEV eluates and lane 2 contains $10 \%$ of the 18 th fraction from the reactive experiments. 
BY4741 (wild-type PRP16) (Baker-Brachmann et al. 1998), prp16-302 (Madhani and Guthrie 1994), and the allele of prp16 in strain DBY4406 (prp16R456K; also see Materials and Methods; Noble and Guthrie 1996). Consistent with its transient interaction with the spliceosome and similar to wild-type Prp2p-TAP (Fig. 1B), affinity-purified, wild-type Prp16p-TAP is not associated with significant levels of spliceosomal snRNAs in the $40 \mathrm{~S}$ region of the gradient (Fig. $5 \mathrm{~A})$. Spliceosomes purified at NPT from prp16 cells are associated with U2, U5, and U6 snRNAs in the $\sim 40 \mathrm{~S}$ region (Fig. 5B).

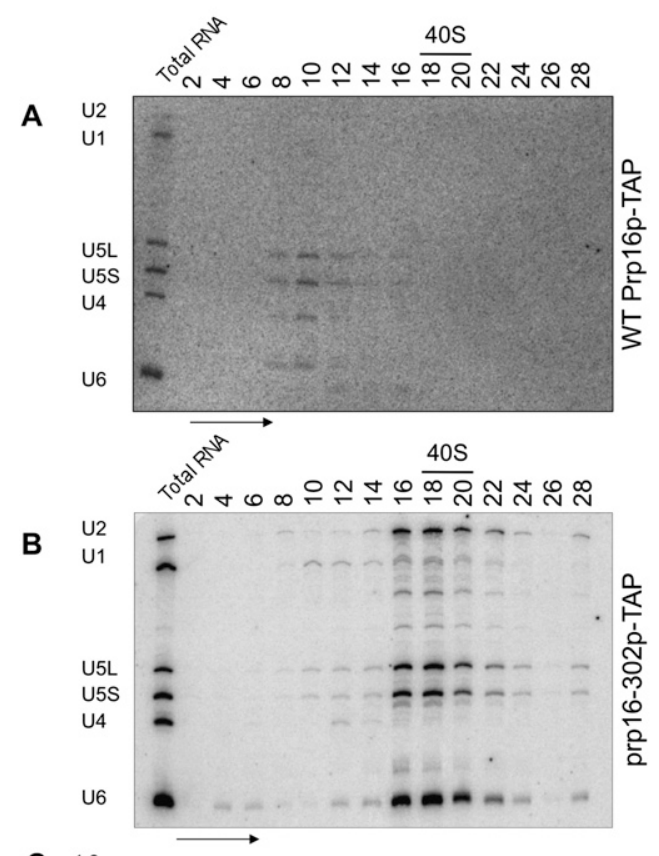

C

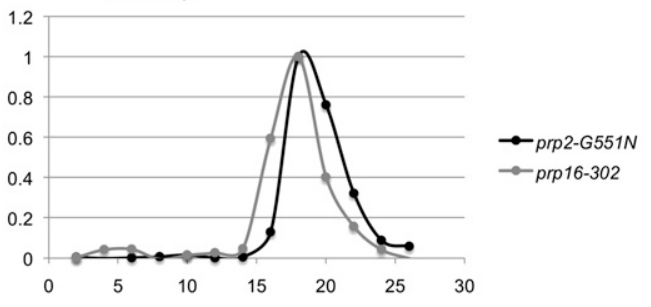

G
We then analyzed the proteins in these second steparrested spliceosomes by MudPIT mass spectrometry analysis. Unlike the first step-arrested spliceosome (Fig. 2), the second step-arrested spliceosome is devoid of all SF3 components. This independently supports that both SF3a and $\mathrm{SF} 3 \mathrm{~b}$ are displaced from the spliceosome between these steps. Other differences include the dissociation of the RES complex (Dziembowski et al. 2004), as well as the addition of the spliceosome disassembly factor Prp43p (Martin et al. 2002).

We measured the difference in sedimentation behavior between the first step-arrested and second step-arrested

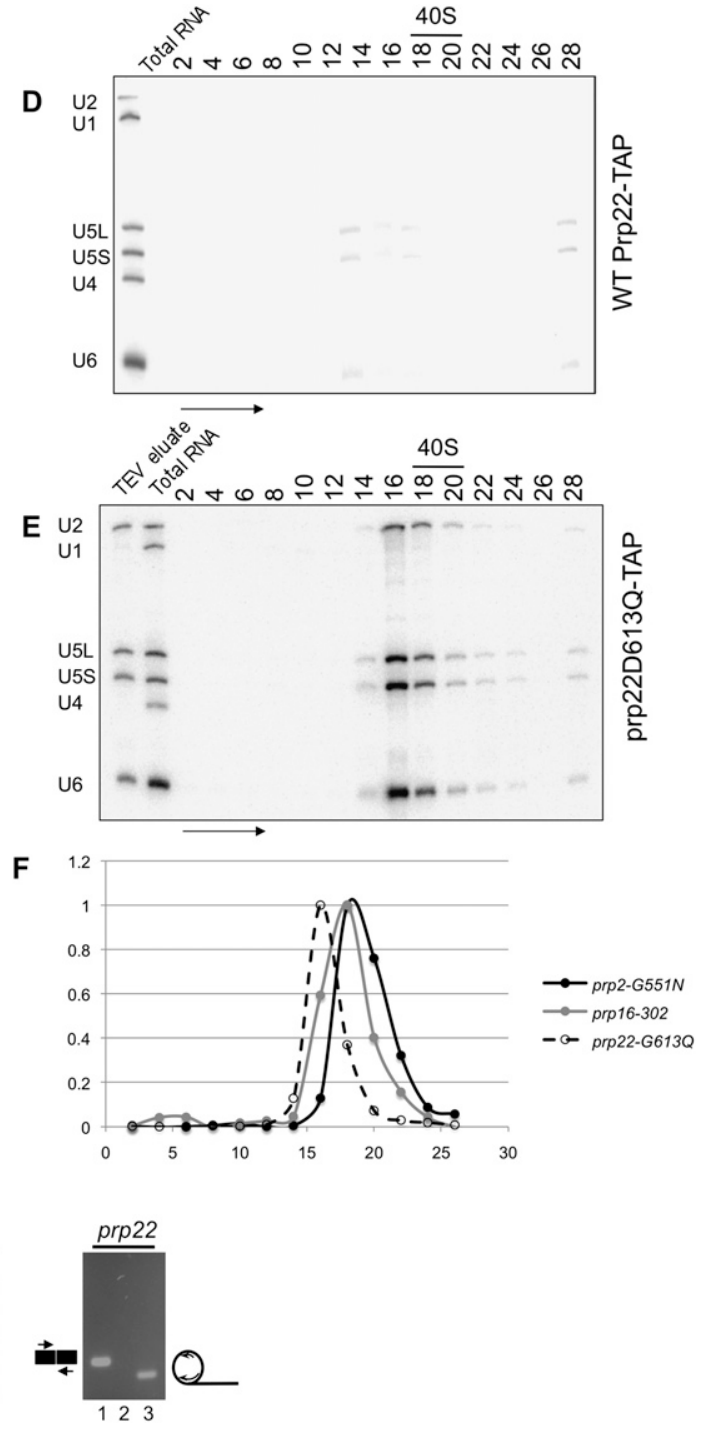

FIGURE 5. Purification of the prp16- and prp22-arrested spliceosomes. RNA from glycerol sedimentation gradients corresponding to affinity purified $(A)$ Prp16p-TAP and $(B)$ prp16-302p-TAP-associated material were Northern blotted for spliceosomal snRNAs. Splicing complexes are present only in the temperature-shifted mutant corresponding to the U2, U5, and U6 snRNAs sedimenting at $\sim 40$. (C) Sedimentation differences between first and second step-arrested spliceosomes were calculated using normalized snRNA signals present in the respective gradient fractions. $(D)$ Prp22p-TAP and (E) prp22-G613Qp-TAP-associated material were Northern blotted for snRNAs as in $A$ and $B$. $(F)$ Graphical representation of sedimentation of prp22-arrested spliceosomes compared to those presented in $C$. $(G)$ RT-PCR analysis of splicing intermediates and products from affinity purified, gradient isolated prp16- and prp22-arrested spliceosomes. First-step products are seen in prp16-arrested spliceosomes. Spliced mRNA and only the lariat intron are present in prp22-arrested spliceosomes. Lanes are as in Figure 3G. 
spliceosomes. Despite the loss of $>500 \mathrm{kDa}$ of SF3 polypeptides, the prp16-arrested spliceosomes do not sediment measurably differently than spliceosomes arrested in the first step after the ATP-independent conformational rearrangement (cf. Fig. 3F and Fig. 5C). This is likely due to the added polypeptide mass of Prp16p, Prp22p, Prp43p, and others, which in total are similar in mass of the displaced SF3 and other first step components (Fig. 2). The similarity in mass and co-sedimentation suggest that there is not a dramatic conformational change after the first step and prior to the action of Prp16p.

\section{Post-splicing prp22-arrested spliceosomes}

After the second step, the spliced mRNA and the intron are retained within the spliceosome until the ATP-dependent function of the DEAH-box protein Prp22p releases the mRNA (Company et al. 1991; Schwer 2008). We completed the DEAH-box-arrested pre-mRNA- or mRNA-containing spliceosome purifications by isolating spliceosomes arrested after the second step, but prior to the release of mRNA using the same TAP-tagging strategy with two cs alleles of prp22 (DBY4172-prp22D613Q and DBY4423prp22G394R,D613Q) (Noble and Guthrie 1996). Similar to that for wild-type Prp2p (Fig. 1B) and Prp16p (Fig. 5A), Prp22p was not associated with significant levels of snRNAs (Fig. 5D). Spliceosomes arrested at the prp22 step were affinity purified and sedimented through a glycerol velocity gradient. RNA extracted from gradient fractions was Northern blotted for snRNAs (Fig. 5E), and the postsplicing prp22-arrested spliceosomes sedimented three fractions higher in the gradient than both the prp2- and prp16arrested spliceosomes (Fig. 5F). There are very few compositional differences between prp16- and prp22-arrested particles, however we note that Yju2p and Cwc25p are absent after Prp16p action and prior to dissociation of the spliceosome.

RT-PCR analysis of the mRNA/pre-mRNA/lariat contained in the peak fractions for prp16- and prp22-arrested spliceosomes was performed (Fig. 5G). As expected, the prp16 spliceosomes contained no pre-mRNA, but did contain the $3^{\prime}$ splice site junction and lariat RNA, indicative of the first step products. The prp22 spliceosomes contained only mRNA and lariat intron, indicative of the post-splicing, second step products. This in vivo evidence is supported by in vitro experiments performed with these mutants (Edwalds-Gilbert et al. 2004; Villa and Guthrie 2005).

Similar to the prp2- and prp16-arrested particles, prp22arrested spliceosomes contain several known spliceosomeassociated proteins present as well as the second step factors Prp18p and Slu7p. These act together after Prp16p is released but prior to Prp22p binding (James et al. 2002). A more complete set of THO/TREX complex components is present in the prp22-arrested spliceosome although
Tho2p is again undetectable. Interestingly, the presence of a deubiquitinase Ubp3p and its interaction partner Bre5p were present in both the prp16- and prp22-arrested spliceosomes. Although no published work has demonstrated a function for these proteins in pre-mRNA splicing, we have also detected these factors in post-splicing lariat RNP complexes (J Combs and SW Stevens, unpubl.).

\section{DISCUSSION}

The pre-mRNA splicing machinery and the mechanism of splicing have been extensively studied by both genetic and biochemical means for many years. Although the basic chemical mechanism of the two transesterification reactions of pre-mRNA splicing was proposed $25 \mathrm{yr}$ ago (Domdey et al. 1984; Padgett et al. 1984; Ruskin et al. 1984), the specific molecular means by which the chemical steps of splicing are authorized and promoted remain unknown. A general mechanism for the function of the DEAH-box protein Prp16p was first proposed by Guthrie and colleagues (Burgess et al. 1990). Work by Query and Konarska (2004) has further shaped this model; however, specific functions for both Prp2p and Prp16p in the first and second step, respectively, have best been described as enigmatic rearrangements.

In this work we show that the mechanism for initiating the attack of the branchpoint adenosine on the 5' splice site involves the removal of SF3 from the spliceosome at the time of Prp2p action, thus unsheathing the pre-mRNA branchpoint/U2 snRNA duplex. Our data support a model in which the U2-associated SF3a and SF3b protein complexes sequester this region and prevent its premature reactivity (Fig. 6; see below).

\section{prp2-, prp16-, and prp22-arrested spliceosomes}

Many important discoveries in the field of pre-mRNA splicing have resulted from compositional comparisons of (1) constituent parts of the spliceosome (Neubauer et al. 1997; Caspary et al. 1999; Stevens and Abelson 1999; Gottschalk et al. 2001; Stevens et al. 2001, 2002), (2) assembled or partially assembled functional complexes (Hartmuth et al. 2002; Jurica et al. 2002; Zhou et al. 2002; Chen et al. 2007; Bessonov et al. 2008), and (3) products of the reaction (Makarov et al. 2002). In this work, we compositionally define spliceosomes arrested at three helicase checkpoints in vivo, each purified by gentle, but stringent affinity chromatography techniques. Due to the differences likely to be encountered through the assembly of the spliceosome in vitro upon a single transcript versus the co-transcriptional assembly of the spliceosome in vivo, we believe that the data presented here accurately represent the composition and functionality of these complexes.

Our mass spectrometry data (Fig. 2) reveal that one striking feature among the helicase-arrested spliceosomes is 


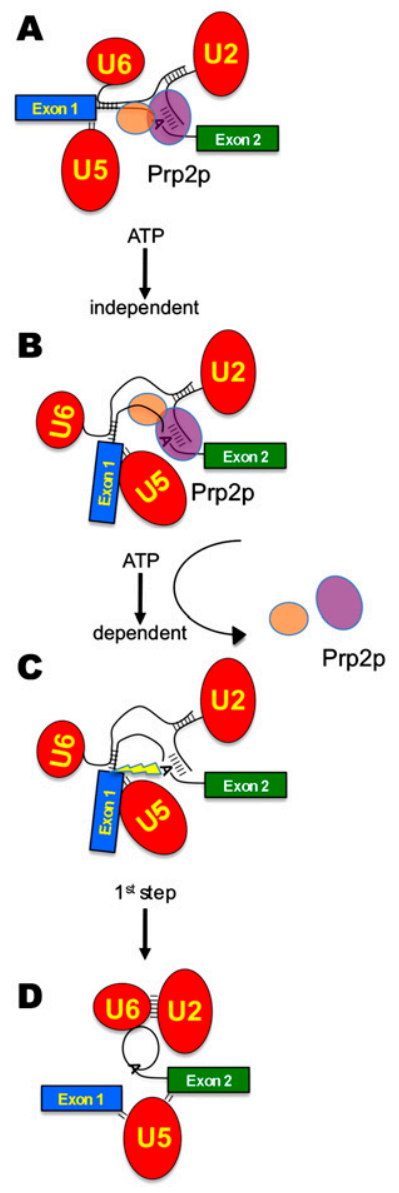

FIGURE 6. Model for the activation of the first chemical step of premRNA splicing. (A) The SF3b complex (purple oval) resides on the branchpoint/U2 RNA duplex, while SF3a (orange oval) resides just upstream of SF3b during spliceosome assembly and until the ATPdependent action of Prp2p. The pre-mRNA is denoted by the green and blue exon boxes and the bottom RNA strand. snRNPs are shown as the red ovals with U2 and U6 snRNAs forming duplexes with each other and the pre-mRNA. U5 snRNP contacts the $5^{\prime}$ splice site. (B) After addition of Prp2p, an ATP-independent rearrangement concomitant with a structural rearrangement occurs. $(C)$ Upon ATP hydrolysis by Prp2p, the SF3a and SF3b components are displaced from the premRNA, uncovering the reactive branchpoint adenosine hydroxyl, which is now properly positioned for in-line attack of the $5^{\prime}$ splice site. $(D)$ Transesterification releases exon 1 and the lariat intermediate, formed by the $2^{\prime}-5^{\prime}$ linkage between the branchpoint and the $5^{\prime}$ splice site.

the absence of most of the U4/U6•U5-associated factors, with the exceptions of the Sm core, Prp8p, Brr2p, and Snu114p, which are present throughout assembly and splicing. Our data show that the majority of U4/U6•U5associated factors are dispensable during the catalytic steps of splicing. This result differs slightly from that of activated human spliceosomes (Makarov et al. 2002) in which other tri-snRNP components were detected. This discrepancy may be due to the operational differences in purifying synchronized splicing complexes formed in vivo versus those formed in vitro, or less likely, might reflect functional differences in the two systems.
More striking is that the SF3a and SF3b components are completely absent after the first step. Other differences between prp2- and prp16-arrested spliceosomes include the addition of factors known to participate in the second step of splicing (e.g., Prp16p, Prp22p), and others that have been implicated in pre-mRNA splicing by association with spliceosomes (e.g., several Cwc proteins), but for which there are not yet data demonstrating a function in splicing. Interestingly, THO/TREX complex components appear only after the first step of splicing and persist through the second step. This temporal difference is consistent with data showing that the THO/TREX complex loads late during transcription on most intron-containing transcripts, after spliceosome assembly (Abruzzi et al. 2004).

We also note that the entire RES complex is absent after the first step of splicing. This heterotrimer has been implicated in the retention of unspliced pre-mRNA in the nucleus and indeed, tagged RES components only co-purify radiolabeled pre-mRNA and no other splicing intermediates (Dziembowski et al. 2004), consistent with our mass spectrometry results. How the RES complex might enforce a nuclear retention phenotype when it is only associated prior to the first step is not currently understood. Other differences between the prp2- and prp16-arrested spliceosomes include the addition of the post-splicing Prp43p helicase (Arenas and Abelson 1997). While Prp43p is not known to be required for the second step or for mRNA release, its presence indicates that it may either have an unknown role at these steps, or that its presence is required or tolerated without playing a catalytic role.

Compositional differences between the prp16- and prp22-arrested spliceosomes are relatively minimal; however, they are consistent with previous reports. These include the addition of Prp18p and Slu7p in the prp22arrested spliceosome; both have been shown to bind and function after the ATPase-dependent function of Prp16p (Jones et al. 1995), but prior to the second step of chemistry. Several THO/TREX complex components are stably bound after the second step. However, in none of the isolated spliceosomes do we find the largest THO/TREX component Tho2p.

Other differences include the removal of Yju2p and Cwc25p after the second step. Previous work from Cheng and colleagues has suggested that these two factors act prior to the first step (Liu et al. 2007; Chiu et al. 2009). Our data demonstrate that in vivo-assembled spliceosomes do not require Yju2p for the first step, at least for the pre-mRNA tested (Fig. 3G), and that Prp2p-initiated removal of SF3a and SF3b also occurs in its absence (Fig. 4B). However, our data cannot rule out that Yju2p joins after Prp2p and prior to the first step. One possibility for this difference is that Yju2p may be required for the splicing of only a subset of introns in yeast. This seems to be the most likely possibility, and indeed, intron microarray analysis has revealed vast differences in splicing efficiency between different splicing 
factor mutants (Pleiss et al. 2007). Another possibility is that the difference between our in vivo-assembled spliceosomes and those formed in vitro using Yju2p-depleted extracts reflect pathway-specific differences resulting from transcription-coupled pre-mRNA processing versus those assembled in vitro. We note that SF3a and SF3b displacement is quantitative under these conditions, independent of the presence of Yju2p in the spliceosomes.

We have not presented data regarding the mechanism of Prp16p in authorizing the second step, however previous work has revealed that a significant change in the conformation of the spliceosome occurs at this stage, inducing protection of the $3^{\prime}$ splice site (Schwer and Guthrie 1992). Our data show a limited number of polypeptides are released at this stage (Fig. 2). If the Prp16p-catalyzed structural rearrangement positions the $5^{\prime}$ exon for attack at the $3^{\prime}$ splice site, it is possible that one or more of the factors that depart at this stage (e.g., Yju2p and/or Cwc25) are protecting the $3^{\prime}-\mathrm{OH}$ of the free $5^{\prime}$ exon and/or sequences around the phosphodiester bond of the $3^{\prime}$ splice site until this point. Candidates for $3^{\prime}$ splice site protection include Prp8p or Prp16p and Prp22p (Umen and Guthrie 1995; McPheeters et al. 2000).

\section{Spliceosome remodeling at the first step of splicing}

Our data show that two rearrangements are affected to initiate the first chemical step of splicing. First, a novel ATP-independent conformational change occurs that is significant enough to shift the sedimentation value of the spliceosome (Fig. 3, cf. B and C and D). This change in the spliceosome may result from a repositioning of a snRNP, the pre-mRNA, or both to favor the arrangement of the reactive sites for the first step (Konarska et al. 2006). Upon ATP treatment, SF3a and SF3b are quantitatively removed from spliceosomes (Figs. 3E, 4A) and pre-mRNA is chased into first step products (Fig. 3G) demonstrating that the prp2 arrested spliceosomes are functional and are not defective, off-pathway intermediates. The spliceosomes purified in this work were prepared under moderately stringent conditions. Purification of spliceosomes using conditions of reduced salt allows pre-mRNA to be chased to fully spliced mRNA (data not shown), likely due to the presence of contaminating amounts of second step factors resulting from less stringent purification.

\section{ATP-independent and ATP-dependent roles for helicases}

Several DExH/D-box proteins have been reported to have both ATP-dependent and ATP-independent functions, including Prp5p during the assembly of the spliceosome (Newnham and Query 2001; Perriman et al. 2003) and Prp22p, which has an ATP-independent role in the second step of splicing (Schwer and Gross 1998) prior to its ATP- dependent role in displacing the spliceosome from the spliced mRNA (Company et al. 1991; Schwer 2008). Similarly, we have shown a parallel ATP-independent rearrangement at the time of $\operatorname{Prp} 2 \mathrm{p}$ function, and defined an ATP-dependent role for Prp2p in initiating the first step of pre-mRNA splicing. Although we cannot yet say definitively that Prp2p is required for the ATP-independent step, the inability to proceed through this step using a prp2 mutant at NPT strongly suggests that Prp2p plays a role. The nature of this event is currently under investigation.

\section{Model for first step activation and catalysis}

Structural analysis of the human SF3b complex demonstrated that the SF3b14a protein, which crosslinks to the branchpoint adenosine (Macmillan et al. 1994) and U2 snRNA (Dybkov et al. 2006), resides in a cleft through which the pre-mRNA has been predicted to thread (Golas et al. 2005). Although yeast SF3b does not contain an ortholog of this protein, the high degree of conservation of the other SF3b subunits suggests that the U2 snRNA/intron branchpoint duplex is sequestered within SF3b in a protective manner.

Others have shown that early in spliceosome assembly, the branchpoint adenosine is arranged in such a way as to expose the reactive $2^{\prime}-\mathrm{OH}$ upon base-pairing to the $\mathrm{U} 2$ snRNA (Newby and Greenbaum 2002). The importance of restraining this highly reactive nucleophile was highlighted in work showing that, in the presence of a defective $5^{\prime}$ splice site, the branchpoint can attack the U2 snRNA itself (Smith et al. 2007). In our model, SF3b provides a temporary steric barrier prior to the activation of the first step of splicing (Fig. 6). Physically obscuring this region at the time of base pairing with the U2-associated SF3b complex allows the numerous rearrangements required to proceed through spliceosome assembly to occur without premature branchpoint reactivity. When the spliceosome achieves the proper conformation (Fig. 6A), an ATP-independent rearrangement occurs (Fig. 6B). Although we do not have direct evidence for the participation of Prp2p in the ATPindependent event, the block induced by prp2G551Np at NPT suggests that Prp2p plays a role in this process. Prp2p then induces an ATP-dependent change that destabilizes both SF3b from the branchpoint region and SF3a from the region upstream of the branchpoint (Fig. 6C). This unleashes the branchpoint $2^{\prime}-\mathrm{OH}$, which is now positioned for proper in-line attack at the $5^{\prime}$ splice site to form the lariat intermediate and free $5^{\prime}$ exon (Fig. 6D).

In this work, we have defined the mechanism of activation of the first step of splicing. Future work should reveal how Prp2p displaces SF3a and SF3b, whether by translocating along the pre-mRNA, as Prp22p does in spliceosome disassembly (Schwer 2008), or by affecting local pre-mRNA or snRNA structure to initiate SF3 release without translocation. 


\section{MATERIALS AND METHODS}

\section{Yeast strains}

The yeast strains used were: SS1347 (MATa, ura3 leu2, trp1, his3, lys2, prp2::TRP1 pRS415-PRP2-TAP::URA3), SS1348 (MATa, ura3, leu2, trp1, his3, lys2, prp2::TRP1 pRS415-prp2G551N-TAP::URA3); SS1353 (MATa ura3, leu2, trp1, his3, lys2, prp2::TRP1 pRS415prp2G551NTAP::URA3 PRP9MYC::HIS); SS1354 (MATa ura3, leu2, trp1, his3, lys2, prp2::TRP1, pRS415-prp2G551NTAP::URA3, HSH155MYC::HIS3); SS1357 (MATa ura3, leu2, trp1, his3, lys2, prp2::TRP1, pRS415-prp2G551NTAP::URA3, PRP9MYC::HIS3, KAN::GAL-HA-YJU2); SS1358 (MATa ura3, leu2, trp1, his3, lys2, prp2::TRP1, pRS415-prp2G551NTAP::URA3, HSH155MYC::HIS3

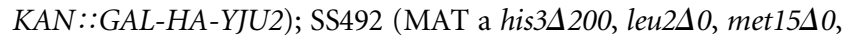
trp1 $\Delta 63$, ura3 $\Delta 0$, PRP16-TAP::TRP1); SS1316 (MAT a ade2, his3, leu2, lys2, trp1, ura3, prp16::LYS2 pSE358-prp16-302-TAP::URA3); SS1311 (parent DBY4406) (MAT $\alpha$ gal-, mal-, his4-619, prp16R456K-TAP::KAN); SS1330 (parent DBY4172) (MAT $\alpha$ gal-, mal-, his4-619, prp22D613Q-TAP::KAN); and SS1332 (parent DBY4423) (gal-, mal-, his4-619, prp22-G394R,D613Q-TAP::KAN).

\section{Mapping helicase mutations}

To map the mutations in the prp16 and prp22 genes in the DBY strains, the entire open reading frame was PCR-amplified from the respective strains. The prp16 mutation contained in DBY4406 is prp16R456K, located just downstream from motif $\mathrm{Ib}$; the mutation in prp22 contained in DBY4172 is D613Q, a charge reversal located just after the DEAH-box (motif II); the mutation in prp22 contained in DBY4423 is G394R, as well as the same D613Q mutation in DBY4172. We note that in addition to the prp2G551N mutation, the prp2 cs mutation used in this work also contains a D547E mutation, which suppresses the dominant negative phenotype reported by Lin and colleagues (EdwaldsGilbert et al. 2000).

\section{Cell growth and temperature shifts}

Wild-type strains were grown in YPD at $31^{\circ} \mathrm{C}$ to $\mathrm{OD}\left(\mathrm{A}_{600}\right)=1.5$ before harvesting. Mutant strains were grown at PT (prp2G551 strains at $37^{\circ} \mathrm{C}$; prp16-302 and prp22 strains at $\left.31^{\circ} \mathrm{C}\right)$ to $\mathrm{OD}\left(\mathrm{A}_{600}\right)=$ 1.0 and then shifted to NPT (prp2G551N strains to $25^{\circ} \mathrm{C}$; prp16302 and $\operatorname{prp} 22$ to $16^{\circ} \mathrm{C}$ ) for $45 \mathrm{~min}$. Cells were harvested by centrifugation, washed in cold water, washed in buffer A $(10 \mathrm{mM}$ HEPES at pH 7.9, $200 \mathrm{mM} \mathrm{KCl}, 1.5 \mathrm{mM} \mathrm{MgCl}_{2}, 0.5 \mathrm{mM}$ DTT, and $10 \%$ glycerol), and resuspended in one volume (w:v) buffer A before freezing dropwise in liquid nitrogen.

\section{Isolation of arrested spliceosomes}

Frozen cells were milled using a Retch ball mill (Mayas et al. 2006). ATP was depleted by addition of glucose to $2 \mathrm{mM}$. Whole cell extract was prepared as described (Stevens and Abelson 2002) except dialysis buffer contained $150 \mathrm{mM} \mathrm{KCl}$. Extract $(40 \mathrm{~mL})$ was incubated with $\operatorname{IgG}$ sepharose $(400 \mu \mathrm{L})$ at $4^{\circ} \mathrm{C}$ for $1 \mathrm{~h}$ with rotation. The resin was washed thoroughly and resuspended in wash buffer (10 mM Tris at $\mathrm{pH} 8.0,150 \mathrm{mM} \mathrm{NaCl}, 0.1 \% \mathrm{NP}-40$, $1.5 \mathrm{mM} \mathrm{MgCl}_{2}, 8 \%$ glycerol, $1 \mathrm{mM}$ DTT, $0.2 \mathrm{mM}$ PMSF). Bound material was incubated for $1 \mathrm{~h}$ at $16^{\circ} \mathrm{C}$ with $\mathrm{TEV}$ protease and RNase inhibitor (Invitrogen). The eluted material was layered onto $10 \%-30 \%$ glycerol gradients (made in $20 \mathrm{mM}$ HEPES at $\mathrm{pH}$ 8.0, $150 \mathrm{mM} \mathrm{KCl}, 1.5 \mathrm{mM} \mathrm{MgCl}, 0.1 \% \mathrm{NP}-40$ ), and were centrifuged for $10 \mathrm{~h}$ at 29,000 RPM in an SW41 rotor. Fractions were phenol/chloroform extracted, and protein and RNA were precipitated (Stevens and Abelson 2002). RNA was subjected to Northern blot analysis probing for U1, U2, U4, U5, and U6 snRNAs, and corresponding protein fractions were subjected to mass spectrometry analysis or Western blot analysis.

\section{Metabolic depletion of YJU2}

Strains containing a metabolically depletable YJU2 gene were grown in $\mathrm{YP}+2 \%$ galactose at $\mathrm{PT}$ to $\mathrm{OD}\left(\mathrm{A}_{600}\right)=0.5$, washed in prewarmed YPD, resuspended in fresh YPD, and allowed to grow for $3 \mathrm{~h}$. Cells were then shifted to $25^{\circ} \mathrm{C}$ for $45 \mathrm{~min}$ before harvesting.

\section{Functional analysis of arrested spliceosomes}

Arrested spliceosomes were purified as described above. Following TEV elution, purified material was treated (1) under splicing conditions (Stevens and Abelson 2002) in the presence of ATP, (2) under splicing conditions in the absence of ATP, or (3) incubated on ice in the absence of ATP. Splicing reactions were layered onto $10 \%-30 \%$ glycerol gradients and centrifuged as described above. Extracted proteins from even fractions were analyzed by Western blotting for the myc tag. Extracted RNA was precipitated and analyzed by Northern blotting for spliceosomal snRNAs.

Native gel electrophoresis of splicing reactions using affinity purified spliceosomes was performed using $20 \mathrm{~cm} \times 20 \mathrm{~cm} \times 0.75 \mathrm{~mm}$ gels $\left(0.5 \mathrm{X}\right.$ TAE and $4 \%$ [80:1]). Gels were electrophoresed at $4^{\circ} \mathrm{C}$ at $250 \mathrm{~V}$ for $11.75 \mathrm{~h}$ in $0.5 \mathrm{X}$ TAE, and analyzed by Northern blotting for U6 snRNA.

For the spliceosome pelleting experiments, TEV elutions were layered on $11 \mathrm{~mL}$ glycerol gradients $(10 \%-30 \%)$ under conditions described above. The peak spliceosome fraction from the glycerol gradient was split into three equal samples. One sample was treated with $1 \mathrm{M} \mathrm{NaCl}$, another adjusted to splicing conditions in the absence of ATP and incubated in ice, and another treated at $37^{\circ} \mathrm{C}$ under splicing conditions with ATP. After a 20 min incubation, each of the samples were layered onto a $30 \%$ glycerol cushion containing $20 \mathrm{mM}$ HEPES at $\mathrm{pH} 7.9,150 \mathrm{mM} \mathrm{KCl}, 1.5 \mathrm{mM}$ $\mathrm{MgCl}_{2}, 0.1 \%$ NP-40, $1 \mathrm{mM}$ DTT, $0.2 \mathrm{mM}$ PMSF, and centrifuged at $80,000 \mathrm{RPM}$ for $80 \mathrm{~min}$ in a TLA 100.3 rotor. The supernatant was removed and the pellet was resuspended. Extracted protein was analyzed by Western blotting for the myc tag.

\section{Protein and RNA quantitation and normalization}

Quantitation of proteins in Western blots was performed using a NightOWL II LB 983 (Berthold Technologies) by ultracold-CCD camera detection. Signal intensities were integrated over the lanes of the Western blot and values for each glycerol gradient fraction were normalized against the lane with the most intense signal, which gave a value of 1 for the most abundant fraction. Automatic average background subtraction was performed for each Western blot independently.

Quantitation of snRNA was performed by phosphorimage analysis using the Quantity One suite of software (Bio-Rad). Values for each band within a Northern blot were quantitated using identically sized analysis frames. Background levels were 
subtracted from each of these values using an identically sized analysis frame in a region of the Northern blot that contained no signal. Background subtracted RNA signals from each glycerol gradient fraction were normalized against the lane with the most intense signal for that Northern blot, which gave a value of one (1) for the most abundant fraction.

\section{RT-PCR}

Peak fractions from the glycerol gradients were treated with DNase I and RNase inhibitor for $15 \mathrm{~min}$ at $37^{\circ} \mathrm{C}$. RNA was phenol extracted, precipitated, and reverse transcribed with AMV reverse transcriptase (Promega) using an oligonucleotide primer specific to the $R P P 1 B$ pre-mRNA/mRNA or the $A C T 1$ lariat/lariat intermediate (J Beggs and D Barrass, pers. comm.). PCR on cDNA was performed using Pfu DNA polymerase using the above primers in pairs designed to detect the species of interest.

\section{Mass spectrometry analysis}

To each sample, $60 \mu \mathrm{L}$ of solubilization buffer (8 M Urea, $100 \mathrm{mM}$ Tris- $\mathrm{HCl}$ at $\mathrm{pH} 8.5)$ were added. The subsequent mixture was then reduced by adding TCEP to $5 \mathrm{mM}$. Iodoacetamide $(10 \mathrm{mM}$ final concentration) was added to alkylate cysteine residues and the samples were subsequently incubated at room temperature in the dark for $15 \mathrm{~min}$. Reactions were diluted to $2 \mathrm{M}$ urea by addition of $180 \mu \mathrm{L}$ of $100 \mathrm{mM}$ Tris at $\mathrm{pH}$ 8.5. Calcium chloride was added to a final concentration of $1 \mathrm{mM}$. Two micrograms of Trypsin were added and the resulting mixtures were shaken for $18 \mathrm{~h}$ in the dark at $37^{\circ} \mathrm{C}$. Formic acid $(90 \%)$ was added to a final concentration of $5 \%$ formic acid. The tubes were centrifuged for $30 \mathrm{~min}$ at $2^{\circ} \mathrm{C}$ on a table top centrifuge.

The protein digest was pressure-loaded onto a fused silica capillary desalting column containing $5 \mathrm{~cm}$ of $5 \mu \mathrm{m}$ Polaris C18-A material (Metachem) packed into a $250 \mu \mathrm{m}$ i.d. capillary with a $2 \mu \mathrm{m}$ filtered union (UpChurch Scientific). The desalting column was washed with buffer containing $95 \%$ water, $5 \%$ acetonitrile, and $0.1 \%$ formic acid. After desalting, a $100 \mu \mathrm{m}$ i.d. capillary with a $5 \mu \mathrm{m}$ pulled tip packed with $10 \mathrm{~cm} 3-\mu \mathrm{m}$ Aqua C18 material (Phenomenex) followed by $3 \mathrm{~cm}$ of $5 \mu \mathrm{m}$ Partisphere strong cation exchanger (Whatman) was attached to the filter union and the entire split-column (desalting column-filter union-analytical column) was placed inline with an Agilent 1100 quaternary HPLC and analyzed using a modified six-step separation described previously (Washburn et al. 2001). The buffer solutions used were 5\% acetonitrile/ $0.1 \%$ formic acid (buffer A), $80 \%$ acetonitrile/ $0.1 \%$ formic acid (buffer B), and $500 \mathrm{mM}$ ammonium acetate/5\% acetonitrile $/ 0.1 \%$ formic acid (buffer C). Step 1 consisted of a 90 -min gradient from $0 \%-100 \%$ buffer B. Steps $2-5$ had the following profile: $3 \mathrm{~min}$ of $100 \%$ buffer A, 2 min of X\% buffer C, a 10 -min gradient from $0 \%-15 \%$ buffer $\mathrm{B}$, and a 97 -min gradient from $15 \%-45 \%$ buffer B. The 2 -min buffer $\mathrm{C}$ percentages (X) were $20 \%, 40 \%, 60 \%$, and $80 \%$, respectively, for the sixstep analysis. For the final step, the elution consisted of: $3 \mathrm{~min}$ of $100 \%$ buffer A, 20 min of $100 \%$ buffer C, a 10-min gradient from $0 \%-15 \%$ buffer $\mathrm{B}$, and a 107 -min gradient from $15 \%-70 \%$ buffer B.

As peptides eluted from the microcapillary column, they were electrosprayed directly into an LTQ two-dimensional ion trap mass spectrometer (ThermoFinnigan) with the application of a distal 2.4-kV spray voltage. A cycle of one full-scan mass spectrum (400-1400 m/z) followed by eight data-dependent MS/MS spectra at a $35 \%$ normalized collision energy was repeated continuously throughout each step of the multidimensional separation. Application of mass spectrometer scan functions and HPLC solvent gradients were controlled by the Xcalibur data system.

MS/MS spectra were analyzed using the following software analysis protocol. Poor quality spectra were removed from the data set using an automated spectral quality assessment algorithm (Bern et al. 2004). MS/MS spectra remaining after filtering were searched with the SEQUEST algorithm (Eng et al. 1994) against the SGD S. cerevisiae (December 16, 2005) protein database (created on December 17, 2006) concatenated to a decoy database in which the sequence for each entry in the original database was reversed (Peng et al. 2003). All searches were parallelized and performed on a Beowulf computer cluster consisting of 100 1.2 GHz Athlon CPUs (Sadygov et al. 2002). No enzyme specificity was considered for any search. SEQUEST results were assembled and filtered using the DTASelect (version 2.0) program (Tabb et al. 2002; Cociorva et al. 2006). DTASelect 2.0 uses a linear discriminant analysis to dynamically set XCorr and DeltaCN thresholds for the entire data set to achieve a userspecified false-positive rate. The false-positive rates are estimated by the program from the number and quality of spectral matches to the decoy database.

Parameters for inclusion in the data presented in Figure 2 include: sequence confirmation of $>5 \%$ of the protein and absence from the mock purification MS/MS data. Mock purification was performed identically to that of the experimental samples from nontagged strain of yeast. Polypeptides identified in this mock analysis as well as contaminants identified in the prp2, prp16, and prp22 particles are presented in Supplemental Table S1.

\section{SUPPLEMENTAL MATERIAL}

Supplemental material can be found at http://www.rnajournal.org.

\section{ACKNOWLEDGMENTS}

We are grateful for helpful conversations with Jean Beggs and contributions of reagents from Christine Guthrie, R.J. Lin, and Beate Schwer. We thank Albert MacKrell, Jennifer Hennigan, and Matthew Sorenson for critically reviewing the manuscript. This work is supported by the NIH by a grant to the Yeast Resource Center to J.R.Y.III (P41 RR11823) and by grants to S.W.S. from the NIH (GM084246), NSF (MCB-0448556), and American Cancer Society (RSG-05-137-01-GMC).

Received November 26, 2009; accepted December 11, 2009.

\section{REFERENCES}

Abovich N, Legrain P, Rosbash M. 1990. The yeast PRP6 gene encodes a U4/U6 small nuclear ribonucleoprotein particle (snRNP) protein, and the PRP9 gene encodes a protein required for U2 snRNP binding. Mol Cell Biol 10: 6417-6425.

Abruzzi KC, Lacadie S, Rosbash M. 2004. Biochemical analysis of TREX complex recruitment to intronless and intron-containing yeast genes. EMBO J 23: 2620-2631. 
Achsel T, Brahms H, Kastner B, Bachi A, Wilm M, Lührmann R. 1999. A doughnut-shaped heteromer of human Sm-like proteins binds to the 3 '-end of U6 snRNA, thereby facilitating U4/U6 duplex formation in vitro. EMBO J 18: 5789-5802.

Arenas JE, Abelson JN. 1997. Prp43: An RNA helicase-like factor involved in spliceosome disassembly. Proc Natl Acad Sci 94: 11798-11802.

Baker-Brachmann C, Davies A, Cost GJ, Caputo E, Li J, Hieter P, Boeke JD. 1998. Designer deletion strains derived from Saccharomyces cerevisiae S288C: A useful set of strains and plasmids for PCR-mediated gene disruption and other applications. Yeast 14: $115-132$.

Behrens SE, Tyc K, Kastner B, Reichelt J, Lührmann R. 1993. Small nuclear ribonucleoprotein (RNP)-U2 contains numerous additional proteins and has a bipartite RNP structure under splicing conditions. Mol Cell Biol 13: 307-319.

Bern M, Goldberg D, McDonald WH, Yates JR 3rd. 2004. Automatic quality assessment of peptide tandem mass spectra. Bioinformatics (Suppl 1) 20: I49-I54.

Bessonov S, Anokhina M, Will CL, Urlaub H, Lührmann R. 2008. Isolation of an active step I spliceosome and composition of its RNP core. Nature 452: 846-850. doi: 10.1038/nature06842.

Bonen L, Vogel J. 2001. The ins and outs of group II introns. Trends Genet 17: 322-331.

Brody E, Abelson J. 1985. The 'spliceosome': Yeast pre-messenger RNA associates with a $40 \mathrm{~S}$ complex in a splicing-dependent reaction. Science 228: 963-967.

Brosi R, Hauri HP, Kramer A. 1993. Separation of splicing factor SF3 into 2 components and purification of SF3a activity. J Biol Chem 268: $17640-17646$.

Burgess S, Couto JR, Guthrie C. 1990. A putative ATP binding protein influences the fidelity of branchpoint recognition in yeast splicing. Cell 60: 705-717.

Caspary F, Séraphin B. 1998. The yeast U2A'/U2B" complex is required for pre-spliceosome formation. EMBO J 17: 6348-6358.

Caspary F, Shevchenko A, Wilm M, Séraphin B. 1999. Partial purification of the yeast U2 snRNP reveals a novel yeast premRNA splicing factor required for pre-spliceosome assembly. EMBO J 18: 3463-3474.

Chan SP, Kao DI, Tsai WY, Cheng SC. 2003. The Prp19p-associated complex in spliceosome activation. Science 302: 279-282.

Chen JH, Lin RJ. 1990. The yeast PRP2 protein, a putative RNAdependent ATPase, shares extensive sequence homology with two other pre-mRNA splicing factors. Nucleic Acids Res 18: 6447. doi: 10.1093/nar/18.21.6447.

Chen Y, Moore R, Ge H, Young M, Lee T, Stevens S. 2007. Proteomic analysis of in vivo-assembled pre-mRNA splicing complexes expands the catalog of participating factors. Nucleic Acids Res 35: 3928-3944.

Chiu YF, Liu YC, Chiang TW, Yeh TC, Tseng CK, Wu NY, Cheng SC. 2009. Cwc25 Is a novel splicing factor required after Prp2 and Yju2 to facilitate the first catalytic reaction. Mol Cell Biol 29: 5671-5678.

Colot HV, Stutz F, Rosbash M. 1996. The yeast splicing factor Mud13p is a commitment complex component and corresponds to CBP20 the small subunit of the nuclear cap-binding complex. Genes \& Dev 10: 1699-1708.

Company M, Arenas J, Abelson J. 1991. Requirement of the RNA helicase-like protein PRP22 for release of messenger RNA from spliceosomes. Nature 349: 487-493.

Cociorva D, Tabb D, Yates JR III. 2006. Validation of tandem mass spectrometry database search results using DTASelect. Curr Protoc Bioinformatics 16: 13.4.1-13.4.14.

Domdey H, Apostol B, Lin RJ, Newman A, Brody E, Abelson J. 1984. Lariat structures are in vivo intermediates in yeast pre-messenger RNA splicing. Cell 39: 611-621.

Dybkov O, Will CL, Deckert J, Behzadnia N, Hartmuth M, Lührmann R. 2006. U2 snRNA-protein contacts in purified human 17S U2 snRNPs and in spliceosomal A and B complexes. Mol Cell Biol 26: 2803-2816.
Dziembowski A, Ventura AP, Rutz B, Caspary F, Faux C, Halgand F, Laprevote O, Séraphin B. 2004. Proteomic analysis identifies a new complex required for nuclear pre-mRNA retention and splicing. EMBO J 23: 4847-4856.

Edwalds-Gilbert G, Kim DH, Kim SH, Tseng YH, Yu Y, Lin RJ. 2000. Dominant negative mutants of the yeast splicing factor Prp2 map to a putative cleft region in helicase domain of $\mathrm{DExD} / \mathrm{H}$-box proteins. RNA 6: 1106-1119.

Edwalds-Gilbert G, Kim DH, Silverman E, Lin RJ. 2004. Definition of a spliceosome interaction domain in yeast Prp2 ATPase. RNA 10: 210-220.

Eng J, McCormack A, Yates J. 1994. An approach to correlate tandem mass spectral data of peptides with amino acid sequences in a protein database. J Am Soc Mass Spectrom 5: 976-989.

Faustino NA, Cooper TA. 2003. Pre-mRNA splicing and disease. Genes \& Dev 17: 419-437.

Fortes P, Kufel J, Fornerod M, Polycarpou-Schwarz M, Lafontaine D, Tollervey D, Mattaj IW. 1999. Genetic and physical interactions involving the yeast nuclear cap-binding complex. Mol Cell Biol 19: 6543-6553.

Golas MM, Sander B, Will CL, Lührmann R, Stark H. 2005. Major conformational change in the complex SF3b upon integration into the spliceosomal U11/U12 di-snRNP as revealed by electron cryomicroscopy. Mol Cell 17: 869-883.

Gottschalk A, Kastner B, Lührmann R, Fabrizio P. 2001. The yeast U5 snRNP coisolated with the U1 snRNP has an unexpected protein composition and includes the splicing factor Aar2p. RNA 7: 15541565.

Gozani O, Feld R, Reed R. 1996. Evidence that sequence-independent binding of highly conserved U2 snRNP proteins upstream of the branch site is required for assembly of spliceosomal complex A. Genes \& Dev 10: 233-243.

Gozani O, Potashkin J, Reed R. 1998. A potential role for U2AF-SAP 155 interactions in recruiting U2 snRNP to the branch site. Mol Cell Biol 18: 4752-4760.

Hartmuth K, Urlaub H, Vornlocher HP, Will CL, Gentzel M, Wilm M, Lührmann R. 2002. Protein composition of human prespliceosomes isolated by a tobramycin affinity-selection method. Proc Natl Acad Sci 99: 16719-16724.

James SA, Turner W, Schwer B. 2002. How Slu7 and Prp18 cooperate in the second step of yeast pre-mRNA splicing. RNA 8: 1068-1077.

Jones MH, Frank DN, Guthrie C. 1995. Characterization and functional ordering of Slu7p and Prp17p during the second step of pre-mRNA splicing in yeast. Proc Natl Acad Sci 92: 96879691.

Jurica MS, Licklider LJ, Gygi SP, Grigorieff N, Moore MJ. 2002. Purification and characterization of native spliceosomes suitable for three-dimensional structural analysis. RNA 8: 426-439.

King DS, Beggs JD. 1990. Interactions of PRP2 protein with premRNA splicing complexes in Saccharomyces cerevisiae. Nucleic Acids Res 18: 6559-6564.

Konarska MM, Vilardell J, Query CC. 2006. Repositioning of the reaction intermediate within the catalytic center of the spliceosome. Mol Cell 21: 543-553.

Legrain P, Choulika A. 1990. The molecular characterization of Prp6 and Prp9 yeast genes reveals a new cysteine histidine motif common to several splicing factors. EMBO J 9: 2775-2781.

Lewis JD, Izaurralde E, Jarmolowski A, McGuigan C, Mattaj IW. 1996. A nuclear cap-binding complex facilitates association of U1 snRNP with the cap-proximal $5^{\prime}$ splice site. Genes \& Dev 10: 1683-1698.

Liu YC, Chen HC, Wu NY, Cheng SC. 2007. A novel splicing factor, Yju2, is associated with NTC and acts after Prp2 in promoting the first catalytic reaction of pre-mRNA splicing. Mol Cell Biol 27: 5403-5413.

Longtine MS, McKenzie A, Demarini DJ, Shah NG, Wach A, Brachat A, Philippsen P, Pringle JR. 1998. Additional modules for versatile and economical PCR-based gene deletion and modification in Saccharomyces cerevisiae. Yeast 14: 953-961. 
Macmillan AM, Query CC, Allerson CR, Chen S, Verdine GL, Sharp PA. 1994. Dynamic association of proteins with the premessenger-RNA branch region. Genes \& Dev 8: 3008-3020.

Madhani HD, Guthrie C. 1994. Genetic interactions between the yeast RNA helicase homolog prp16 and spliceosomal snRNAs identify candidate ligands for the prp16 RNA-dependent ATPase. Genetics 137: 677-687.

Makarov EM, Makarova OV, Urlaub H, Gentzel M, Will CL, Wilm M, Lührmann R. 2002. Small nuclear ribonucleoprotein remodeling during catalytic activation of the spliceosome. Science 298: 22052208.

Martin A, Schneider S, Schwer B. 2002. Prp43 is an essential RNAdependent ATPase required for release of lariat-intron from the spliceosome. J Biol Chem 277: 17743-17750.

Mayas RM, Maita H, Staley JP. 2006. Exon ligation is proofread by the DExD/H-box ATPase Prp22p. Nat Struct Mol Biol 13: 482-490.

McPheeters DS, Schwer B, Muhlenkamp P. 2000. Interaction of the yeast DExH-box RNA helicase Prp22p with the $3^{\prime}$ splice site during the second step of nuclear pre-mRNA splicing. Nucleic Acids Res 28: 1313-1321.

Neubauer G, Gottschalk A, Fabrizio P, Séraphin B, Lührmann R, Mann M. 1997. Identification of the proteins of the yeast U1 small nuclear ribonucleoprotein complex by mass spectrometry. Proc Natl Acad Sci 94: 385-390.

Newby MI, Greenbaum NL. 2002. Sculpting of the spliceosomal branch site recognition motif by a conserved pseudouridine. Nat Struct Biol 9: 958-965.

Newnham CM, Query CC. 2001. The ATP requirement for U2 snRNP addition is linked to the pre-mRNA region $5^{\prime}$ to the branch site. RNA 7: 1298-1309.

Noble SM, Guthrie C. 1996. Identification of novel genes required for yeast pre-mRNA splicing by means of cold-sensitive mutations. Genetics 143: 67-80.

Padgett RA, Konarska MM, Grabowski PJ, Hardy SF, Sharp PA. 1984. Lariat RNAs as intermediates and products in the splicing og messenger-RNA precursors. Science 225: 898-903.

Peng J, Elias JE, Thoreen CC, Licklider LJ, Gygi SP. 2003. Evaluation of multidimensional chromatography coupled with tandem mass spectrometry (LC/LC-MS/MS) for large-scale protein analysis: The yeast proteome. J Proteome Res 2: 43-50.

Perriman R, Barta I, Voeltz GK, Abelson J, Ares M. 2003. ATP requirement for Prp5p function is determined by Cus $2 p$ and the structure of U2 small nuclear RNA. Proc Natl Acad Sci 100: 13857-13862.

Pleiss JA, Whitworth GB, Bergkessel M, Guthrie C. 2007. Transcript specificity in yeast pre-mRNA splicing revealed by mutations in core spliceosomal components. PLoS Biol 5: 745-757.

Puig O, Caspary F, Rigaut G, Rutz B, Bouveret E, Bragado-Nilsson E, Wilm M, Séraphin B. 2001. The tandem affinity purification (TAP) method: A general procedure of protein complex purification. Methods 24: 218-229.

Query CC, Konarska MM. 2004. Suppression of multiple substrate mutations by spliceosomal prp8 alleles suggests functional correlations with ribosomal ambiguity mutants. Mol Cell 14: 343-354.

Ruskin B, Krainer AR, Maniatis T, Green MR. 1984. Excision of an intact intron as a novel lariat structure during pre-mRNA splicing in vitro. Cell 38: $317-331$.
Sadygov RG, Eng J, Durr E, Saraf A, McDonald H, MacCoss MJ, Yates JR III. 2002. Code developments to improve the efficiency of automated MS/MS spectra interpretation. J Proteome Res 2: 211215.

Sapra AK, Khandelia P, Vijayraghavan U. 2008. The splicing factor Prp17 interacts with the U2, U5, and U6 snRNPs and associates with the spliceosome pre- and post-catalysis. Biochem J 416: 365-374.

Schwer B. 2008. A conformational rearrangement in the spliceosome sets the stage for prp22-dependent mRNA release. Mol Cell 30: 743-754.

Schwer B, Gross CH. 1998. Prp22, a DExH-box RNA helicase, plays two distinct roles in yeast pre-mRNA splicing. EMBO J 17: 20862094.

Schwer B, Guthrie C. 1991. PRP16 is an RNA-dependent ATPase that interacts transiently with the spliceosome. Nature 349: 494-499.

Schwer B, Guthrie C. 1992. A conformational rearrangement in the spliceosome is dependent on PRP16 and ATP hydrolysis. EMBO J 11: 5033-5039.

Séraphin B. 1995. Sm and Sm-like proteins belong to a large family-identification of proteins of the $\mathrm{U} 6$ as well as the U1, U2, U4, and U5 snRNPs. EMBO J 14: 2089-2098.

Smith DJ, Query CC, Konarska MM. 2007. Trans-splicing to spliceosomal U2 snRNA suggests disruption of branch site-U2 pairing during pre-mRNA splicing. Mol Cell 26: 883-890.

Staley JP, Guthrie C. 1998. Mechanical devices of the spliceosome: Motors, clocks, springs, and things. Cell 92: 315-326.

Stevens SW, Abelson J. 1999. Purification of the yeast U4/U6•U5 small nuclear ribonucleoprotein particle and identification of its proteins. Proc Natl Acad Sci 96: 7226-7231.

Stevens SW, Abelson J. 2002. Yeast pre-mRNA splicing: Methods, mechanisms, and machinery. Methods Enzymol 351: 200-220.

Stevens SW, Barta I, Ge HY, Moore RE, Young MK, Lee TD, Abelson J. 2001. Biochemical and genetic analyses of the U5, U6, and U4/U6•U5 small nuclear ribonucleoproteins from Saccharomyces cerevisiae. RNA 7: 1543-1553.

Stevens SW, Ryan DE, Ge HY, Moore RE, Young MK, Lee TD, Abelson J. 2002. Composition and functional characterization of the yeast spliceosomal Penta-snRNP. Mol Cell 9: 31-44.

Tabb DL, McDonald WH, Yates JR III. 2002. DTASelect and Contrast: Tools for assembling and comparing protein identifications from shotgun proteomics. J Proteome Res 1: 21-26.

Umen JG, Guthrie C. 1995. Prp16p, Slu7p, and Prp8p interact with the $3^{\prime}$ splice site in two distinct stages during the second catalytic step of pre-mRNA splicing. RNA 1: 584-597.

Villa T, Guthrie C. 2005. The Isylp component of the NineTeen Complex interacts with the ATPase Prp16p to regulate the fidelity of pre-mRNA splicing. Genes \& Dev 19: 1894-1904.

Washburn MP, Wolters D, Yates JR III. 2001. Large-scale analysis of the yeast proteome by multidimensional protein identification technology. Nat Biotechnol 19: 242-247.

Will CL, Urlaub H, Achsel T, Gentzel M, Wilm M, Lührmann R. 2002. Characterization of novel SF3b and 17S U2 snRNP proteins, including a human Prp5p homologue and an SF3b DEAD-box protein. EMBO J 21: 4978-4988.

Zhou Z, Licklider LJ, Gygi SP, Reed R. 2002. Comprehensive analysis of the human spliceosome. Nature 419: 182-185. 

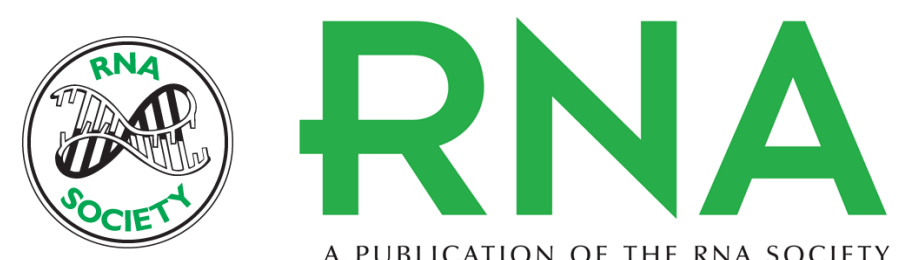

A PUBLICATION OF THE RNA SOCIETY

\section{Release of SF3 from the intron branchpoint activates the first step of pre-mRNA splicing}

Rea M. Lardelli, James X. Thompson, John R. Yates III, et al.

RNA 2010 16: 516-528 originally published online January 20, 2010

Access the most recent version at doi:10.1261/rna.2030510

\section{Supplemental http://rnajournal.cshlp.org/content/suppl/2010/01/19/rna.2030510.DC1 \\ Material}

References This article cites 79 articles, 38 of which can be accessed free at:

http://rnajournal.cshlp.org/content/16/3/516.full.html\#ref-list-1

\section{License}

Email Alerting Receive free email alerts when new articles cite this article - sign up in the box at the Service top right corner of the article or click here. 